\title{
THE EFFECT OF COMMUNICATIVE APPROACH ON SPEAKING ACHIEVEMENT
}

\author{
Ilyas \\ STAIN Watampone \\ ilyas@gmail.com
}

\begin{abstract}
This paper aims at finding out whether or not communication Approach affect students' achievement in speaking class. This research was experimental research, which aims to find out the effectiveness of communicative approach for improving the process of English language teaching and learning. The population of this research were the fourth semester of STAIN Watampone which consists of 44 students. From this number, the research took 22 students randomly as the sample of the research. Those students were divided into two classes, namely 11 students in experimental class and 11 students in the control class. The instrument of this research was observation checklist and speaking test. Communicative approach can improve students' speaking achievement at STAIN Watampone. It was indicated by the result of $\mathrm{t}$ test that the $\mathrm{t}$ - observation was higher than $\mathrm{t}$-table value, where $\mathrm{t}$ observation $=2,204>\mathrm{t}$ - table $=2.086$, at .05 levels of significance with a degree of freedom of 20. This data indicates that there is a significant difference between students' speaking achievement taught by using communicative approach than taught by using conventional method. It could be stated that the application of communicative approach in teaching speaking could improve the students' speaking achievement better than the conventional applied.
\end{abstract}

Keywords: Communicative Approach, Speaking Achievement

\section{A. INTRODUCTION}

$\mathrm{I}$

$\mathrm{n}$ this globalization era, English is an important language and plays an important role for communication in many parts of the world. Many people use it as means of communication, science, technology, art and social relation. One who knows English well tends to easily apply for a job and truncate his business. We cannot deny that the mastery of English especially speaking is quite necessary for Indonesian people.

Based on the researcher's experiences in giving lecture on English at STAIN Watampone around 7 years he concludes that average students still lack of English speaking. This statement is proved by the fact in the process of teaching in the classroom, interaction when presenting the English lecture.

The objectives of English teaching in Indonesian as stated in the instructional programmed guidelines for university are to enable the students in English given text books used in tertiary education; to understand lectures in English given by foreign lecture; to write certain note in English to other foreigners in general (Rasyid, 1988).

English has been taught from junior high school up to university however, the fact shows that the most of Indonesian students can not use English well, particularly in 
Ilyas, The Effect of Communicative Approach on Speaking Acbievement...

speaking. Muttaqin (1992) stated that most of English students still fail in using English as a tool of communication.

It is right students need to learn language, but the problem comes later is how should they learn language? This is the matter of methodology or strategy in learning process. The students should apply certain strategy in learning language, especially English as a foreign language for Indonesian students. Concerning this matter, some experts have conducted researches on this matter. Some findings are collected by Wenden and Rubin in their Learner Strategies in Language Learning (1987). They also define the term of learning strategy as (1) language learning behaviors learners actually engage in o learn and regulate the learning, (2) learners know about the strategy they use, and (3) what learners know about aspects of their language learning other than the strategy they use (Wenden and Rubin, 1978).

In addition, students still need some support or facility in learning although there are some students who can learn by themselves, self-regulated learners in this case. Selfregulated learner can be a good model for all learners. It is right but not all students have motivation as high as they are who learn with their self-regulation. This fact now becomes as central issue in education. What about the other students? Should their parents or teachers, for them who have been sent to school, just learn by themselves? It that the most effective strategy to be conducted for all students? Neill (in Palmer, 2003) actually agrees to say 'yes' replying these questions because he is sure than students' licenses, which is different from freedom according to him, is able to led them into professional persons in what disciplines they involve. This opinion is also supported by Topatimasang (2003). He offers a future school with no person, but nature and experience as the teacher.

The opinions of the two experts above may have a little Tightness but, once again, it is very individual. It cannot be generalized into all students and all circumstances. Students at any instances need teachers and institutions to learn more effective. This case refers to the teachers' responsibility together with schools as their institution. Teachers and schools as social institution for education, therefore, play a very important rule in the development of students' ability, including speaking. Teachers may teach or educate their students in their schools with special rules and learning materials depending on policy of government and institution. In has been clear up to this stage that students need learning strategy and teacher. Teachers on the purpose hand must also have special strategy in teaching in order that they reach the purpose of education. For this concern, teachers need to know some teaching or educating methods. There are two terms presented, teaching and educating, because those are similar, not really the same. Teaching may refer to a more specific purpose, cognitive, and educating refers to broader once, including behavior and emotion. This becomes also a big responsible for teachers and their schools. Drost in his suggests teachers to educate, not merely educate their students to speak for example. 
Richards and Rodgesr presented some approaches and methods. One of them is communicative language teaching (2001). Communicative is an approach language teaching that may effective to develop students' active participation. Lado (1988) suggests one principle that apply to practical mastery of the language, namely active participation in language by the students. It is essential to good language teaching to provide ample participation of the students in meaningful language use. Merely explaining or describing the language - that is, talking about it - or merely letting the students listen to it without comprehension is in inadequate. For example, when the students are learning information questions, give them the task of being a reporter. Have them ask each other questions about interests, works, etc., and report to the class. Teacher may also invite a guess to the class and have the students question him/her.

Therefore, teachers have to encourage students' active participations specially in speaking class. This is very important for language learners because speaking is an active skill of language. Students therefore do not have other ways to get speaking ability or speaking competence expect through active participation is speaking.

Speaking in English for Indonesian students, much less the student of STAIN Watampone is found so difficult. This is believed through the pre-observation done by the researcher that most students of STAIN Watampone have much less fluency in speaking English. They are very reluctant in speaking or participating actively in speaking class. This fact motivates the researcher to think the problem over. The researcher is sure that there must be a way to cure the students from their disease, less speaking, in their class. The researcher therefore intends to conduct a research under the focus on the effect of communicative approach on student's active participation in speaking class.

Based on the background above, problem statement of this research is "does the communicative approach bring positive effects on students' participation in speaking class?"

\section{B. LITERATURE REVIEW}

The students' participation in speaking class in indicated by the involvement of the students in the class activity. In this case, the frequency and the duration of the students' speaking are the indicators of their participation. Therefore, the more frequent and the longer they are speaking, the better their participation in speaking class.

Since the mid of the nineteenth century up to now, there have been many methods that are still recognized, such as Grammar, Translation method, Direct Method, Audio Lingual Method, Cognitive Approach, Communicative Approach.

In the following problem, the communicative approach will be presented briefly. Davis (1989: 103) describes the communicative approach as a way of teaching English as a 
Ilyas, The Effect of Communicative Approach on Speaking Acbievement...

foreign language (EFL) students learn through using the language and have many opportunities to interact with each other and with the teacher.

For the sane thing, Littlewood (1982: 1) states that the ultimate goal of language teaching is developing the learners' ability to take part in the process of communicating through language. To develop communicative skill, they have to put the language into practice. This theory encourages an emphasis on practice as a way of developing communicative skill. He further says that communicative language teaching pays systematically attention to functional as well as structural aspects of language such as follows:

"One of the most characteristic features of communicative language teaching is that

it pays systematic attention to functional as well as structural aspect of language, combining these into a more fully communicative view" (Little Wood, 1982).

While Nunan (1991: 279) in Brown (1994: 78) offers features to characteristic CLT:

1. An emphasis on learning to communicative through interaction in the target language.

2. The introduction of authentic text into the learning situation.

3. The provision of opportunities for learner to focus, not only on languages but also on the learning process itself.

4. An enhancement of the learners owns personal experiences as important contributing elements to classroom learning.

5. An attempt to link classroom language learning with language activation outside the classroom.

In teaching of the communicative English, teacher should realize that integration of the context is important. Johnson and Morrow (1981: 6) state as follows:

In a communicative approach on the other hand, integration is a means of providing natural context for language use. Sometimes the context will care for speaking, sometimes for writing, sometime for combination of skills. The skills used depend upon the activities involved and ...... as well as individual skills, can be developed into an integral sequence".

Interaction in the classroom is necessary for a communicative operation, as follows: "The communicative approach on the other hand, make sure that interactions which take in the classroom are replication of, or necessary prerequisites for, a communicative operation."(Johnson and Morrow, 1981:71).

Communicative approach can be divided into two versions as stated by Howatt (1984: 279) in Richards and Rodgers (1986: 66):

"There is, in a sense, a 'strong' version of the communicative approach and a 'weak' version which has become more or less standard practice in the last ten years, stresses the importance of providing learners with opportunities to use their English for communicative purposes and, characteristically, attempts to integrated such activities into a wider program of language teaching The 'strong' version communicative teaching on the 
other hand, advances the claim that language is acquired through communication, so that it is not merely a question of activating an existing but inert knowledge system itself. If the former could be described as 'learning to use' English, the latter entails 'using English to learn it'.

Furthermore, Harmer (1983: 38) states that a methodological approach to the teaching of languages which takes of input, (both roughly-and finely-tuned), practice, and communication input. Many writers have called it the communicative approach to language teaching. Thus is because its aims are overtly communicative and great emphasis, as we have see, is paced on training students to use language for communication. The communicative approach is, then, an umbrella term to describe methodology which teaches students how to communicative efficiently and which lays emphasis on the teaching of communicative value and, is some cases, the teaching of language functions. While Wilkin (1983: 24) gives definition on CLT such as follows: thus, communicatively may be seen to lie in the priority of conversational interaction over other modes of language behavior, in a syllabus of "nations and functions" as opposed to "non-authentic" materials, in an emphasis on "process" rather than "product" or in the desire to base language on genuine communication rather than on participation in pedagogically motivated and structured activities. Perhaps, for the present, we shall have to be satisfied that this is as close as we can get to a definition of CLT. In addition, William puts forward the major characteristic of CLT appear to be three. At the level of syllabus design the dominant feature is relevance to learners' need; at the level of methodology the concern is with meaningful communication; at the level of material it with authenticity.

Brown (1987: 213) offers the following four interconnected characteristics as a definition of CLT: (1) Classroom goals are focused on all of the components of communicative competence and not restricted to the grammatical or linguistic competence. (2) Form is not the primary framework for organizing and sequencing lessons. Function is the framework through which forms is taught. (3) Accuracy is secondary to conveying a massage. Fluency may take on more importance than accuracy. The ultimate criterion for communicative success is the actual transmission and receiving odd intended meaning. (4) In the communicative classroom, students ultimately have to use the, language, productively and receptively, in unrehearsed context.

Johnson (1987: 10) states that 'communicative language teaching' is one, which recognize the teaching of 'communicative competence' as its aim. It is on this level of aim that such a language teaching distinguishes itself from more traditional approaches where the emphasis is heavily on teaching structural competence. We may thus see the revision of aims as enrichment an acceptance that there are further dimension of language, which need teaching. 
Ilyas, The Effect of Communicative Approach on Speaking Acbievement...

With reference to the quotation above, the communicative language teaching in Indonesian belongs to the 'weak version' of communicative approach.

Then a couple of decades later, Richars and Rodgers proposed a reformulation approach, method, and technique of the concept of method. Anthony's approach, method, and technique were renamed, respectively, with approach, design, and procedure, with super ordinate term to describe this three-step processes now called 'method'. A method, according to Richards and Rodgers (1985: 16), is an 'umbrella term' for specification and interrelation of theory and practice. They state that the primary areas needing further clarification are, using Anthony's term, method, and technique. We see approach and method treated at the level of design, that level in which objectives, syllabus, and context are determined, and in which the roles of teacher, learners, and instructional materials are specified. The implementation phase (the level of technique in Athony's model) we refer to, by the slightly more comprehensive term procedure. Thus, a method is theoretically related to an approach, is organizationally determined by a design, and is practically realized in procedure.

\section{RESEARCH METHOD}

This research was experimental research, which aims to find out the effectiveness of communicative approach for improving the process of English language teaching and learning. To meet that purpose, this research took the true-experimental design that just use post-test, random subject to two groups (Ary, 1982)

The population of this research were the fourth semester of STAIN Watampone which consists of 44 students. From this number, the research took 22 students randomly as the sample of the research. Those students were divided into two classes, namely 11 students in experimental class and 11 students in the control class.

The instrument of this research was speaking test. The researcher used observation checklist to record students' expression language production. In this observation checklist, the research noted every activity that is related to students' participation in the speaking class.

\section{FINDINGS AND DISCUSSION}

\section{Students speaking achievement taught by using communicative approach}

The Pretest was given before the treatment. The results are shown in the Table 3. Of the 11 students of experimental group, there were 2 (18,1 percent) students who classified 'very poor', 2 (18,1 percent) students 'poor', 5 (45,5 percent) students 'fair', 1 (9,9 percent) student 'fairly good, 1 (9,9 percent) student 'good' and none of them were classified as 'very good', and 'excellent'. The table shows that the rate percentage of the students' score on pretest on experiment group was in fair classification. 
The Posttest was given after the treatment using communicative approach. Based on data got in posttest, it shows that none of the students who classified as 'poor' to 'very poor', 2 (18,1 percent) students 'fair', 2 (18,1 percent) student 'fairly good', 5 (45,4 percent) students 'good', 1 (9,9 percent) student 'very good' and 1 (9,9 percent) student classified as 'excellent'. It means that the teaching of speaking by using communicative approach can improve the students' active participant.

The achievement of the group on active participant in speaking class is shown by the mean score of the group. The writer found that from pretest to posttest, group achievement of the 11 experiment students of STAIN Watampone increased from 1.63 (classified as 'fair') to 2,75 (classified as 'good') after the treatment. The mean score of the experiment group before the treatment was 1,63 and the standard deviation was 0,48 . After the treatment the mean score was 2,75 and the standard deviation was 0,56 . It means that the mean score increased about 1,12 point.

\section{The Students' Achievement on Speaking Taught by Using Audio-Lingual Method}

The data in control class in pretest shows that there were 2 (6.66 percent) students who were classified 'good', 3 (27,3 percent) students 'fair', 4 (36,4 percent) students 'poor', 2 (18,1 percent) students 'very poor' and none of them got 'excellent, very good, even 'fairly good'. This shows that the achievement of the students placed in the control group is relatively the same with the students placed in the experiment group.

While on posstest the data shows that among 11 control students, none of the students who classified as 'excellent' and 'very poor', 2 (18,1 percent) students 'very good', 1 (9,9 percent) student 'good', 2 (18,1 percent) students 'fairly good', 5 (45,4 percent) students 'fair', and 1 (9,9 percent) student who classified as 'poor'.

The data shows that the students' speaking on posttest was different of the total students in the control group, 100 percent were classified between 'very good' to 'poor'. While the students in the experiment group, 100 percent were classified between 'excellent' to 'fair'. It means, "there was an increasing result" from the pretest.

Group achievement of the control group increased from 1,60 (classified as 'fair') in pretest to 2,17 (classified as 'fairly good') in posttest. The data shows that the mean score of the control group before the treatment was 1,60 and the standard deviation was Q.,54. After the treatment the mean score was 2,17 and the standard deviation was 0,64. It means that the mean score increased about 1,43 point.

Based on the analysis of pretest of experiment and control group, the results of the $t-$ test were found in the Table 9.

Table 9. The calculation result of the pretest

\begin{tabular}{|c|c|c|}
\hline Calculation & $\begin{array}{c}\text { Experiment } \\
\left(\mathbf{X}_{1}\right)\end{array}$ & $\begin{array}{c}\text { Control } \\
\left(\mathbf{X}_{2}\right)\end{array}$ \\
\hline$\sum X$ & 17,9 & 17,6 \\
\hline
\end{tabular}


Ilyas, The Effect of Communicative Approach on Speaking Achievement . . .

\begin{tabular}{|c|c|c|}
\hline $\mathrm{X}$ & 1,63 & 1,60 \\
\hline $\mathrm{SD}$ & 0,48 & 0,54 \\
\hline $\mathrm{SS}$ & 2,54 & 3,24 \\
\hline$\sum \mathrm{X}^{2}$ & 31,67 & 31,40 \\
\hline$\left(\sum \mathrm{X}^{2}\right)$ & 320,41 & 309,76 \\
\hline $\mathrm{t}$-obs. & \multicolumn{2}{|c|}{0,13} \\
\hline t-tab & \multicolumn{2}{|c|}{1,72} \\
\hline $\mathrm{df}$ & \multicolumn{2}{|c|}{20} \\
\hline
\end{tabular}

The result obtained above shown $\mathrm{t}$ - observation $=0.17<\mathrm{t}$ - table $=1,72$, at .05 levels of significance with a degree of freedom of 20 indicates that $\mathrm{HO}$ is acceptable or $\mathrm{H}_{3}$ is rejected, so there is not significant. It means that the mean scores of experiment group and control group were relatively the same. Those experiment group and control group have the same or relatively the same baseline knowledge before the treatment.

The experiment group ( $\mathrm{Xi}$ ) was taught by using communicative approach and the control group $\left(\mathrm{X}_{2}\right)$ was taught by using audio-lingual method. After the treatment, the students in both groups were post tested to find out their result whether their achievement on reading comprehension were at the same level or not. The results of posttest are presented on the table

Table 10. The calculation result of the posttest

\begin{tabular}{|c|c|c|}
\hline Calculation & $\begin{array}{c}\text { Experiment } \\
\left(\mathbf{X}_{\mathbf{1}}\right)\end{array}$ & $\begin{array}{c}\text { Control } \\
\left(\mathbf{X}_{\mathbf{2}}\right)\end{array}$ \\
\hline$\sum \mathrm{X}$ & 30,3 & 23,9 \\
\hline $\mathrm{X}$ & 2,75 & 2,17 \\
\hline $\mathrm{SD}$ & 0,56 & 0,64 \\
\hline $\mathrm{SS}$ & 3,45 & 4,56 \\
\hline$\sum \mathrm{X}^{2}$ & 86,91 & 56,49 \\
\hline$\left(\sum \mathrm{X}^{2}\right)$ & 918,09 & 572,21 \\
\hline t-obs. & \multicolumn{2}{|}{} \\
\hline t-tab & \multicolumn{2}{|c|}{1,72} \\
\hline $\mathrm{df}$ & \multicolumn{2}{|c|}{20} \\
\hline
\end{tabular}

The table informed us that the t- observation was higher than t-table value, where $\mathrm{t}$ observation $=2,164>\mathrm{t}$ - table $=1,72$, at .05 levels of significance with a degree of freedom of 20. This data indicates that the statistical hypothesis of $\mathrm{H}_{\mathrm{o}}$ was rejected and of course, the statistical hypothesis of $\mathrm{H}_{1}$ was acceptable. It means that the students' achievement on speaking taught by using communicative approach was able to give significantly greater contribution than the student's achievement on speaking taught by using audio-lingual method. It could be stated that the application of communicative approach in teaching speaking could improve the students' ability and their achievement better than the audiolingual applied.

In this section, the discussion deals with the effectiveness of communicative approach in teaching speaking. The application of communicative approach and audio- 
lingual method in teaching speaking to the students of STAIN Watampone can improve the students' achievement on speaking. It was proved by the mean score of both groups. Before the treatment, the mean score of the experimental group was 1,63 (fair classification) and after the treatment, the mean score was 2,75 (good classification) where 45,4 percent of students were classified on 'good' classification and the others 9,9 percent were classified on 'very good', and 18,1 percent were on 'fairly good' classification.

Then, the difference of the students' achievement on speaking was proved by the ttest value (t-test formula for independent sample) on posttest $\mathrm{T}$ - observation value was $2,164>\mathrm{t}$ - table was 1,72, at .05 levels of significance with a degree of freedom of 20. This data can indicate that the two materials are significantly different in improving the students' achievement on speaking. It means the hypothesis in the last part of Chapter II is true, that is, there is significant difference of speaking achievement between the students taught by using communicative approach and those taught by using audio-lingual method. If the result of this research give significant difference achievement on speaking between experimental and control group, it means that the teaching of speaking by using communicative approach at STAIN Watampone is better than the teaching of speaking by using audio-lingual method does.

This result was supported by some theories in the chapter II. Littlewood (1982: 1) states that the ultimate goal of language teaching is developing the learners' ability to take part in the process of communicating through language. To develop communicative skill, they have to put the language into practice. This theory encourages an emphasis on practice as a way of developing communicative skill.

In a communicative approach, integration is a means of providing natural context for language use. Sometimes the context will care for speaking, sometimes for writing, sometime for combination of skills. The skills used depend upon the activities involved.

Since communication is a process, it is insufficient for the students to simply have knowledge of target language forms, meanings, and functions. Students must be able to apply this knowledge in negotiating meaning. It is through the interaction between speaker and listener that meanings become clear. The listener gives the speaker feedback as to whether or not he understands what the speaker has said. In this way, the speaker can revise what he has said and try to communicate his intended meaning again, if necessary.

The application of communicative approach in teaching speaking, the teacher divides the teaching and learning activities into three stages, (1) introduction stage, (2) practice to production stage, (3) feedback stage.

In terms of introduction stage, the students get warmed to the topic so that they are interested and motivated. A lot of current topic can be given to arouse the students' interest. 
Ilyas, The Effect of Communicative Approach on Speaking Acbievement...

In terms of practice to production stage, the discussion activities encourage students to speak more, to systematize and elaborate their knowledge and to find out the new words or unfamiliar words for the students.

With regard to the feedback stage, principally the teachers should evaluate the students based on the given topic in the discussion at that time.

\section{E. CONCLUSION}

Based on the research findings and discussion in the previous chapter, the study has come out with the following conclusion:

1. The achievements of the students on speaking taught by communicative approach at STAIN Watampone are 18,1 percent 'fair', 18,1 percent 'fairly good', 45,4 percent 'good', and 9,9 percent 'very good' and 'excellent' level of classification. The data informed that the mean score of experimental group on posttest $=2,75$ (good classification) is higher than the mean score on pretest $=1,63$ (fair classification). The mean score of experimental group increased about 1,12 points.

2. The achievements of the students on speaking taught by using audio- lingual method at STAIN Watampone are 9,9 percent 'poor', 45,4 percent 'fair', 18,1 percent 'fairly good', 9,9 percent 'good', and 18,1 percent 'very good' level of classification.

3. The finding of this research through tabulated data shows that the mean score of posttest of experimental group is higher than the mean score of posttest of control group $(2,75>2,17)$. The result of the data analysis shows that t-observation - 2,164> t-table - 1,27, at 0,05 level of significant and 20 degrees of freedom. It means that $\mathrm{H}_{\text {, }}$ is rejected and $\mathrm{Hi}$ is acceptable. So, there is significant difference of achievement on speaking between the students taught by using communicative approach and those taught by using audio-lingual method. Communicative approach can improve the achievement of the students on speaking better than audio-lingual method.

\section{REFERENCES}

Adler, Ronal and Rod man. (1995). Understanding Human Communication, New York: CBS College Publishing

Ary, Donald. (1982). Pengantar Penelitian dalam Pendidikan. Surabaya: Usaha Nasional

Atkinson, D. (1987) _ The Mother Tongue in the Classroom: A Neglected Resource ETL Journal, 41, 4 pp. 241 - 247.

Auerbach E. (1993). Reexaming English only in the ESL Classroom. TESOL Quarterly 27, 1, pp. $9-32$ 
Borich, Gary D. (1992). Effective Teaching Method. New York: Macmillan Publishing Company

Byrne. (1976). Oral Communication. New York: Random House, Inc.

Darjowodjojo, Soenjono. (2003). Psikolinguistik: Pengantar Pemahaman Bahasa Manusia. Jakarta: Yayasan Obor Indonesia.

Das Bikram K. (ed). (1985). Communicative Language Teaching. Singapore: SEAMEO Regional Language Centre

Drost. (1998). Sekolah, Mengajar atan Mendidik? Yogyakarta: Kanisius.

Fiske, John. (1982). Introduction to Communication Studies. London: Methuen \& Co, Ltd.

Freire, Paulo. (2000). Pendidikan sebagai Proses: Surat-Menyurat Pedagogis dengan para Pendidik Guinea-bissau. Yogyakarta: Pustaka Pelajar.

. (2002). Politik Pendidikan: Kebudayaan, Kekuasaan dan Pembebasan. Yogyakarta: Pustaka Pelajar.

Gay. (2006). Educational Research. Ohio: Charles E. Merril Publishing Company and A Bell \& Howell Company

Gonzales. (1982). Finding of the Effect of Communicative Approach on Language Use in Philippine Classroom. Manila: Philippine.

Harmer, Jeremy. (1991). The Practice of English Language Teaching. New York: Longman Group UK.

Higgins. J. M. (1982). Human Relation. New York: Random House, Inc.

Kennedy, Chris. (1983). Language Planning and Language education. London: George Alien \& Unwin.

Lado, Robert. (1988). Teaching English Across Culture. United State: Me. Graw-Hill.

Naomi, Omi Intan (ed). (2003). Menggugat Pendidikan: Fundamentalis, Konservatif, Liberal, Anarkis. Yogyakarta: Pustaka Pelajar.

O'Malley, J. Michael and Anna Uhl Chamot. (1990). Learning Strategy in Second Language Acquisition. Cambridge: Cambridge University Press.

Topatimasang, Roem. (2003). Sekolah Itu Candu. Yogyakarta: Pustaka Pelajar.

Wedden \& Rubin. (1978). Learner Strategy in Language Learning. Oxford: Oxford University Press.

Widdowson, H, G. (1983). Teaching as Communication. Oxford: Oxford University Press. 